International Journal of Advanced Chemistry, 9 (2) (2021) 156-160
International Journal of Advanced Chemistry
SPC
Website: www.sciencepubco.com/index.php/IJET
Research paper

\title{
Concentration level of arsenic in agricultural soil and surface water used for irrigation in Bukuru, JOS- south LGA of plateau state, Nigeria
}

\author{
Dodo J. D. ${ }^{1}$, Akinola C.O. ${ }^{2}$, Ogah E. ${ }^{1}$, Salami S. J. ${ }^{1}$ \\ ${ }^{1}$ Lecturer Department of Chemistry, Faculty of Natural Sciences, University of Jos, Jos. Nigeria \\ ${ }^{2}$ Student Department of Chemistry, Faculty of Natural Sciences, University of Jos, Jos. Nigeria \\ *Corresponding author E-mail: dodojuliet1969@gmail.com
}

\begin{abstract}
Arsenic concentration of agricultural soil and surface water used for irrigation were surveyed in two abandoned mining sites of Jos South Local Government Area. DB-Zang and Dorowa total dissolved solid, total hardness, electrical conductivity, temperature and $\mathrm{pH}$ of the agricultural soil and surface water were determined according to standard procedure. Result indicates that Total dissolve solids in W1 was $156 \pm 2.00 \mathrm{mg} / \mathrm{L}$ and for $\mathrm{W} 2(160 \pm 2.00 \mathrm{mg} / \mathrm{L})$, total hardness $\mathrm{W} 1(35.20 \pm 4.70 \mathrm{mg} / \mathrm{L})$ and $\mathrm{W} 2(44.67 \pm 4.70 \mathrm{mg} / \mathrm{L})$, electrical conductivity for W1 was $0.240 \pm 0.189 \mu \mathrm{s} / \mathrm{cm}$ and W2 was $0.120 \pm 0.189 \mu \mathrm{s} / \mathrm{cm}$, electrical conductivity for S1 $(0.49 \pm 0.16 \mu \mathrm{s} / \mathrm{cm}), \mathrm{S} 2(0.17 \pm 0.16 \mu \mathrm{s} / \mathrm{cm})$, temperature for both water was $28.00 \pm 0.00^{\circ} \mathrm{C}$ for soil are $18.00 \pm 0.00{ }^{\circ} \mathrm{C}, \mathrm{pH}$ for W1 (7.10 \pm 0.05$)$ and W2 (7.20 \pm 0.05$), \mathrm{pH}$ for $\mathrm{S} 1(6.90 \pm 0.15)$ S2 ( $6.60 \pm 0.15)$. The concentration of Arsenic in soil L2 is $14.00 \pm 0.70 \mu \mathrm{g} / \mathrm{kg}$ which is in agreement with WHO recommended level of Arsenic in soil and for L1 $257.00 \pm 120.00 \mu \mathrm{g} / \mathrm{kg}$ which is not in agreement with the WHO recommended level of arsenic, while in water for $\mathrm{L} 1$ was $3.00 \pm 0.50 \mu \mathrm{g} / \mathrm{L}$ which is not in agreement with the WHO recommended level of arsenic and L2 was $48.00 \pm 0.70 \mu \mathrm{g} / \mathrm{L}$ which is not in agreement with the WHO recommended level of arsenic. The cultivation of food crops in those areas are not recommended.
\end{abstract}

Keywords: Agricultural Soil; Arsenic; Concentration; Physicochemical Properties; Surface Water.

\section{Introduction}

Arsenic is an abundant component of the earth's crust. As a result, the potential for human exposure to arsenic is very high. This potential is even higher for people living in regions with particularly high arsenic concentrations, whether occurring naturally or as a result of industrial activities (Walter 2015).

Arsenic is a well-known poisonous substance and classed as being carcinogenic to humans. Epidemiological studies have indicated that arsenic is able to increase risk of cancers of lung, liver, bladder, and skin in human, and more than a million people are suffering from arsenic-contaminated ion in drinking water worldwide (WHO 2018).

\subsection{Physical and chemical properties of arsenic}

Arsenic is a silver-grey brittle, crystalline (hexagonal, rhombic), metallic-looking substance which exists in three allotropic forms (yellow, black, and grey). It is odorless and nearly tasteless. It is soluble in nitric acid, cold hydrochloric, and sulfuric acids. It is insoluble in water and nonoxidizing acids. Pure arsenic can be heated to burn in air, giving off an odour of garlic and white fumes of arsenic trioxide

Arsenic is odourless and is usually combined with one or more other elements such as oxygen, chlorine and Sulphur. Pure arsenic is not soluble in water or organic solvents, but can be dissolved by strong acids. Arsenic trioxide is sparingly soluble in water.

Soil is biologically active, porous medium that has developed in the uppermost layer of Earth's crust. Soil is one of the principal substrata of life on Earth, serving as a reservoir of water and nutrients, as a medium for the filtration and breakdown of injurious wastes, and as a participant in the cycling of carbon and other elements through the global ecosystem. It has evolved through weathering processes driven by biological, climatic, geologic, and topographic influences.

\subsection{Arsenic in water}

Lubyanka \& Vladana (2018) determined arsenic in water depending on the physical, chemical and biogeochemical processes and condition of the environment, various arsenic species can be present in water. Water soluble arsenic species existing in natural water are inorganic arsenic and organic arsenic species. All acidic species, according to the chemical equilibrium, have well-recognized molecular and ionic forms in water. The distribution of species is a function of $\mathrm{pH}$ value of water are found in groundwater, lakes, rivers and ocean. The WHO provisional guideline value for arsenic in drinking water is $10 \mu \mathrm{g} \mathrm{L}^{-1}$. The most selective and sensitive methods for determination of total 
arsenic and its species in water are coupled techniques including chromatography, optical methods and mass spectrometry. Determination of arsenic species is of crucial importance for selection of arsenic removal technology. Best available technologies are based on adsorption, precipitation, membrane and hybrid membrane processes. Adsorption is considered to be relatively simple, efficient and low-cost removal technique, and convenient for application in rural areas. Sorbents for arsenic removal are biological materials, mineral oxides, activated carbons and polymer resins.

WHO (2018) reported that at least 140 million people of 50 countries are exposed to arsenic through arsenic-contaminated groundwater at levels above $10 \mu \mathrm{g} / \mathrm{L}$ and a majority of them live in India and Bangladesh? In Bangladesh and India, the groundwater arsenic contamination initially emerged as a major health issue, and later came to be known as the worst arsenic-affected countries in the world in terms of population exposure to arsenic-contaminated water.

Shiv et al (2014) revealed arsenic contamination of groundwater in different parts of the world as an outcome of natural and/or anthropogenic sources, leading to adverse effects on human health and ecosystem. Millions of people from different countries are heavily dependent on groundwater containing elevated level of As for drinking purposes. As contamination of groundwater, poses a serious risk to human health. Excessive and prolonged exposure of inorganic As with drinking water is causing arsenicosis, a deteriorating and disabling disease characterized by skin lesions and pigmentation of the skin, patches on palm of the hands and soles of the feet. Arsenic poisoning culminates into potentially fatal diseases like skin and internal cancers. This paper reviews sources, speciation, and mobility of As and global overview of groundwater As contamination. The paper also critically reviews the As led human health risks, its uptake, metabolism, and toxicity mechanisms. The paper provides an overview of the state-of-the-art knowledge on the alternative As free drinking water and various technologies (oxidation, coagulation flocculation, adsorption, and microbial) for mitigation of the problem of As contamination of groundwater.

\subsection{Arsenic in soil}

Different soils have varying background concentrations of As depending on the parent material of soils; in most cases, the baseline soil As content can range from 5 to $10 \mathrm{mg} \mathrm{kg}^{-1}$. For European topsoil, an average As concentration of $7 \mathrm{mg} \mathrm{kg}^{-1}$ has been reported. On the other hand, peats and bog soils are relatively more enriched with As, where average soil As concentrations of up to $13 \mathrm{mg} \mathrm{kg}^{-1} \mathrm{have}$ been noted. Acid sulfate soils are amongst the other soils that have comparatively more soil As levels. For many countries of the world, the United States Environmental Protection Agency (USEPA)'s recommended permissible soil As concentration of $24 \mathrm{mg} \mathrm{kg}^{-1}$ has been surpassed due to various anthropogenic activities (Wuana \& Okieimen 2011).

The natural content of arsenic found in soils varies between $0.01 \mathrm{mg} / \mathrm{kg}$ and a few hundred milligrams per kilogram. Anthropogenic sources of arsenic in the environment are the smelting of ores, the burning of coal, and the use of arsenic compounds in many products and production processes in the past. A lot of arsenic compounds are toxic and cause acute and chronic poisoning. In aqueous environment the inorganic arsenic species arsenite (As (III)) and arsenate (As (V)) are the most abundant species. The mobility of these species is influenced by the $\mathrm{pH}$ value, the redox potential, and the presence of adsorbents such as oxides and hydroxides of Fe (III), $\mathrm{Al}$ (III), Mn (III/IV), humic substances, and clay minerals, Monique et al. (2003).

\section{Methodology}

\subsection{Study area}

The samples were collected in the area of Jos South local government area (Bukuru), the sample location is DB-Zang dam (Living Faith DB-Zang) behind the stadium and Dorowa (Dam). It is a noticeable area where mining operation has been carried out which contribute to the contamination of the water and soil, the inhabitants use the area for agricultural irrigation activities both in the rainy and dry season because of the availability of the water. Sample location are also presented on the map of study area (Fig1). Three samples at each sampling point were collected for soil and water in total of six (6) samples for soil and six (6) sample for water.

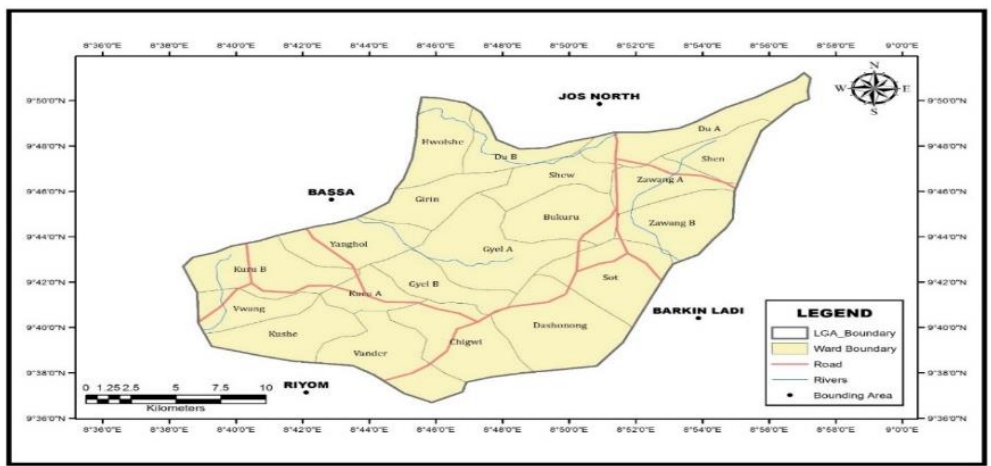

Fig. 1: Map of Jos South Local Government Plateau State Showing the Sample Area Source: Geospatial Analysis Mapping and Environmental Research Solutions.

\subsection{Sample collection}

The sampling was done in the month of January 2020. Two sampling spots were mapped out for soil and water sample collection within the sampling sites.

\subsubsection{Soil sample}

The soil samples were collected from two different farm land which are: DB-Zang and Dorowa irrigated with water where mining operation has been carried out. The samples were collected in a clean polythene bag and were thoroughly mixed. The soil sample were labelled sample S(A) and S(B) in triplicate respectively. There are different kinds of vegetables and tubers planted on the farmland in which they 
use the water (dam) for irrigation farming for the vegetables and tubers planted on the farmland which include spinach, lettuce, sweet and Irish potatoes, cabbage, spring onions and so on.

\subsubsection{Water sample}

The water samples were collected in 1litre capacity polythene bottles previously cleaned with metal free detergent, rinsed with distilled water from the two locations which are DB-Zang and Dorowa. The samples were label W(A) and W(B) in triplicate respectively.

\subsection{Sample preparation}

\subsubsection{Soil sample}

The soil samples were collected different polythene bags, properly labelled and immediately taken to the laboratory where they were properly dried for one week (7days) at room temperature. There were then crushed with a mortar and pestle and sieved with $2 \mathrm{~mm}$ mesh and then oven dried for $72 \mathrm{hrs}$ before stored in a sample bottle for analysis.

\subsubsection{Water sample}

After sample collection, the samples were labeled and taken to the laboratory for preservation by treating with concentrated nitric acid $\left(\mathrm{HNO}_{3}\right)$ and kept in refrigerator with the temperature maintained below $60^{\circ} \mathrm{C}$ throughout the period before the analysis.

\subsection{Determination of temperature}

The temperature of the water sample was determined by dipping the thermometer into the water to get the current temperature of the water on the location.

\subsection{Determination of soil pH}

$1.0 \mathrm{~g}$ of dried soil samples from each site were mixed with $20 \mathrm{ml}$ of deionized water in a $50 \mathrm{ml}$ beaker and stirred with a glass rod. The $\mathrm{pH}$ was measured by introducing a glass probe of the $\mathrm{pH}$ into the soil solution and read out.

\subsection{Determination of total dissolve solid (TDS)}

A clean evaporating dish was heated in a drying oven at temperature of $105^{\circ} \mathrm{C}$ for about 30 minutes. It was then cool in desiccator for about 10 minutes. Then the dish was weighted carefully on a balance, with the weight recorded and the weight was labelled as A. About $100 \mathrm{ml}$ of water was added and evaporated to dryness and then transferred to oven at $105^{\circ} \mathrm{C}$ and dried for about $1-2$ hours. The dish was allowed to cool in air, which was later placed in a desiccator while still warm to complete the cooling process. The dish was weighted as soon as it cooled and recorded as B.

Calculation

$$
\text { Total solid in } \mathrm{mg} / \mathrm{L}=\frac{B-A \times 100}{m l \text { of sample }}
$$

Where $\mathrm{B}=$ weight of residue and dish

$\mathrm{A}=$ weight of the dish alone

\subsection{Determination of electrical conductivity}

The conductivity meter with a reference electrode was rinsed with distilled water, and immersed in the water sample to be analyzed. It was allowed to stand for few seconds after which the results were displayed for successive samples.

\subsection{Determination of total hardness}

$50 \mathrm{ml}$ of water sample is pipette into $100 \mathrm{ml}$ conical flask followed by $2 \mathrm{ml}$ of ammonium chloride buffer. A little pinch of Erichrome T black powder was added. The solution was then titrated immediately with $0.01 \mathrm{M}$ EDTA and mixed continuously until the colour changed to clear blue. The volume of EDTA used was noted at end point.

Calculation

Total hardness $=m l$ of $E D T A \times 1000$

ml of sample

\subsubsection{Digestion of soil sample}

To different samples in the beakers, $20 \mathrm{ml}$ of concentrated nitric acid $\left(\mathrm{HNO}_{3}\right)$ was added to $2 \mathrm{~g}$ of soil samples, they were left overnight; The samples were shaken mechanically for 30 minutes then heated on a heating mantle under the fume cupboard at about $95^{\circ} \mathrm{C}$ for 10minutes it was brought down from the heating mantle and were allowed to cool then filtered into $100 \mathrm{ml}$ of volumetric flask using Whatman filter paper (No.1). It was made up to $100 \mathrm{mls}$ with distilled water. The filtrates were then analyzed for Arsenic (As) using Atomic Absorption Spectroscopy (AAS) AA990.

\subsubsection{Digestion of water sample}

To the different samples in the beakers, $20 \mathrm{ml}$ of nitric acid $\left(\mathrm{HNO}_{3}\right)$ was added to $5 \mathrm{ml}$ of water sample and left to stay overnight; the samples were shaken mechanically for 30 minutes and then heated on a heating mantle under the fume cupboard at $95^{\circ} \mathrm{C}$ for 10 minutes. They were brought down from the heating mantle and were allowed to cool, filtered into $100 \mathrm{ml}$ of volumetric flask using Whatman filter paper (No.1) 
and funnel. It was made up to $100 \mathrm{mls}$ with distilled water. The filtrates were then analyzed for Arsenic (As) using Atomic Absorption Spectroscopy (AAS) AA990.

\subsection{Determination of the concentration of arsenic in surface water (used for irrigation) and agricultural soil}

Based on beer-lambert theory Atomic Absorption Spectroscopy light beam is directed towards a monochromator through the flame and unto detector that measures the amount of absorbed light. The vapour of an element which contains free atoms absorbs light having wavelength equal to that which the atoms of the element are capable of emitting. When light of this wavelength passes through a flame containing a cloud of free atoms of the respective element, the intensity of the ray is reduced due to absorption. The measured decreased intensity of the light is proportional to the concentration of atoms in the solution.

\section{Results}

The results for the determination of physicochemical properties of the soil and water samples are presented in Table 1 and 2 respectively while Table 3 reveals the concentration of arsenic in both water and soil at the two sample locations.

Table 1: Determination of Temperature, Ph, Electrical Conductivity, Total Hardness and Total Dissolved Solid for Water Sample

\begin{tabular}{llllll}
\hline LOCATION & $\mathrm{pH}$ & $\begin{array}{l}\text { TEMPERATURE } \\
{ }^{\circ} \mathrm{C}\end{array}$ & $\begin{array}{l}\text { TOTAL HARDNESS } \\
\mathrm{mg} / \mathrm{l}\end{array}$ & $\begin{array}{l}\text { ELECTRICAL CONDUCTIVITY } \\
\mathrm{ms} / \mathrm{cm}\end{array}$ & $\begin{array}{l}\text { TOTAL DISSOLVE } \\
\text { SOLID mg/l }\end{array}$ \\
\hline $\mathrm{W}_{1}$ & $7.10 \pm 0.05$ & $28.00 \pm 0.00$ & $35.20 \pm 4.70$ & $0.240 \pm 0.189$ & $156 \pm 2.00$ \\
$(\mathrm{DB}-\mathrm{ZANG})$ & & & & $0.120 \pm 0.189$ & $160 \pm 2.00$ \\
$\mathrm{~W}_{2}$ & $7.20 \pm 0.05$ & $28.00 \pm 0.00$ & $44.67 \pm 4.70$ & $0.00-19.90$ & 500.00 \\
$\begin{array}{l}\text { (DOROWA) } \\
\text { WHO STAND- }\end{array}$ & $6.50-8.50$ & $27.00-30.00$ & 500 & \\
ARD & & & & \\
\hline
\end{tabular}

Table 2: Determination of the Temperature, $\mathrm{Ph}$ and Electrical Conductivity for Agricultural Soil in Location A (DB-Zang) and Location B (Dorowa)

\begin{tabular}{|c|c|c|c|}
\hline LOCATION & $\mathrm{pH}$ & TEMPERATURE $^{\circ} \mathrm{C}$ & ELECTRICAL CONDUCTIVITY $\mathrm{ms} / \mathrm{cm}$ \\
\hline $\begin{array}{l}\mathrm{S}_{1} \\
\text { (DB-ZANG) }\end{array}$ & $6.90 \pm 0.15$ & $18.00 \pm 0.00$ & $0.49 \pm 0.16$ \\
\hline $\begin{array}{l}\mathrm{S}_{2} \\
\text { (DOROWA) }\end{array}$ & $6.60 \pm 0.15$ & $18.00 \pm 0.00$ & $0.17 \pm 0.16$ \\
\hline WHO STANDARD & $6.50-8.50$ & $27.00-30.00$ & 19.90 \\
\hline
\end{tabular}

Table 3: Mean Concentration of Arsenic in Soil and Water Obtained from Location A and B (DB-Zang and Dorowa)

\begin{tabular}{llc}
\hline LOCATION & CONCENTRATION & WHO Standard \\
\hline W $_{1}$ & $3.00 \pm 0.50 \mu \mathrm{g} / \mathrm{l}$ & $10.00 \mu \mathrm{g} / \mathrm{l}$ \\
DB-ZANG & $48.00 \pm 0.70 \mu \mathrm{g} / \mathrm{l}$ & $10.00 \mu \mathrm{g} / \mathrm{l}$ \\
$\mathrm{W}_{2}$ & $257.00 \pm 120.00 \mu \mathrm{g} / \mathrm{kg}$ & $10.00 \mu \mathrm{g} / \mathrm{l}$ \\
DOROWA & $14.00 \pm 7.00 \mu \mathrm{g} / \mathrm{kg}$ & $40.00 \mu \mathrm{g} / \mathrm{kg}$ \\
S $_{1}$ & DB-ZANG & \\
S & & \\
DOROWA & & \\
\hline
\end{tabular}

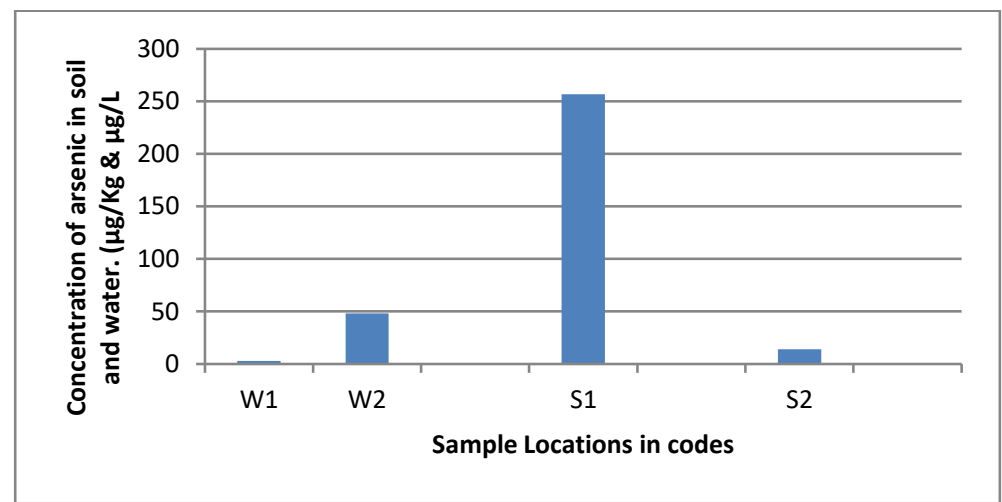

Fig. 2: Bar Chart Showing Concentration of Arsenic Soil and Water from Sampling Sites.

\section{Discussion}

$\mathrm{pH}$ is the measure of alkalinity or acidity of water. The World Health Organization (WHO) standard pH for drinking water is within the range of 6.5-8.5. (WHO, 2018). The results obtained for water at DB Zang was $3.00 \pm 0.5$ and Dorowa was $48.00 \pm 0.7$ shows that the water is safe for domestic usage as the respective values falls within the range of WHO quality standard. The values of the $\mathrm{pH}$ ranges from $7.1-$ 7.2 which indicate that the surface water samples are basic and are in agreement with what was reported by other researchers which are within the range of 6.5-8.9 in similar study (Edimeh et al 2011, Aremu et al 2011).

The average temperature of water samples of the study area was $28{ }^{\circ} \mathrm{C}$ for both location and in the range of $28-29{ }^{\circ} \mathrm{C}$. Temperature in this study was found within permissible limit of WHO $\left(30^{\circ} \mathrm{C}\right)$. Ezeribe $(2012)$ reports similar result $\left(29^{\circ} \mathrm{C}\right)$ of well water in Nigeria.

Water has the ability to dissolve a wide range of inorganic and some organic minerals and salts such as potassium, calcium, sodium, bicarbonates, chlorides, magnesium, sulphates etc. These minerals produce unwanted taste and diluted colour in appearance of water. 
Standard limit for TDS is 500mg/L (WHO 2018). The TDS in drinking water value was in the range of 156 and $160 \mathrm{mg} / \mathrm{L}$. The mean total dissolved solids at DB-ZANG were found to be $156 \mathrm{mg} / \mathrm{l}$, DOROWA IS $160 \mathrm{mg} / \mathrm{l}$ and it is within the limit of WHO standards. Water containing high solid may cause laxative or constipation effects. According to Sasikaran et al. (2012).

Hardness is defined as the concentration of calcium and magnesium ions expressed in terms of calcium carbonate. The presence of carbonates/ bicarbonates may cause poor lather formation and scales on boilers (Durrance 1986). Soap reacts with these minerals to form "soap scum" when hard water is boiled using home heater, it forms solid deposit of calcium carbonate, this scale can reduce the life of equipment, raise the cost of heating the water, lower the efficiency of electric water heaters and clog pipes. But hard water has some benefits too and based on the classification of hard water by WHO, sample W1 and W2 are low. The total hardness of the both waters are low compared to the WHO standard.

Pure water is not a good conductor of electric current rather a good insulator. Increase in ion concentration enhances the electrical conductivity of water. Generally, the number of dissolved solids in water determines the electrical conductivity. Electrical conductivity (EC) actually measures the ionic process of a solution that enables it to transmit current. According to WHO standards, EC value should not exceed $400 \mu \mathrm{S} / \mathrm{cm}$.

The physiochemical properties of the agricultural soil and surface water which are pH., Total Dissolved Solid, Temperature, Total Hardness and Electrical Conductivity has no effect on the agricultural soil and surface water according to the result obtained in Tables 3 and 4. Arsenic is present in surface water in Site (A) which is DB-Zang, the mean concentration is $3.0 \pm 0.5 \mu \mathrm{g} / \mathrm{l}$ and in a minute quantity. Arsenic is present in agricultural soil in location (A) which is DB-Zang and in higher quantity the mean concentration is $257 \pm 120 \mu \mathrm{g} / \mathrm{kg}$ which is higher than the permissible limit of $40 \mu \mathrm{g} / \mathrm{kg}$ World Health Organization (WHO 2018).

Arsenic is present in agricultural soil in location (B) which is Dorowa the mean concentration is $14 \pm 0.7 \mu \mathrm{g} / \mathrm{kg}$ its lower than the permissible limit $40 \mu \mathrm{g} / \mathrm{kg}$ of WHO standard.

Arsenic is present in surface water in location (A) which is DOROWA the mean concentration is $48 \pm 0.7 \mu \mathrm{g} / \mathrm{l}$ the concentration level is higher than the permissible limit $10 \mu \mathrm{g} / \mathrm{l}$ of WHO standard.

\section{Conclusion}

This research work is based on determination of arsenic concentration in agricultural soil and surface water used for irrigation. The study revealed the presence of arsenic in soil and water to be above the permissible limit of WHO (2018). Therefore, the sites are not fit for cultivation.

Following adequate and careful comparison of results of the various analyses with the standards for World Health Organization (WHO), the following recommendations are made.

Mining and industrial activities should be discouraged in these areas because such activities expose the people around those areas to pollution i.e., the toxic metals underground to the surface and therefore serves as a source of pollution of the soil and water used for agricultural purposes.

\section{References}

[1] Aremu MO, Olaofe O, Ikokoh PP \& Yakubu MM (2011) Physicochemical characteristics of stream, well and borehole water sources in Nasarawa Eggon, Nasarawa State, Nigeria. Journal Chemical Society Nigeria, 36 (1), 131-136. https://doi.org/10.5772/intechopen.75531.

[2] Durrance EM (1986) Radioactivity in Geology. Principles and Applications. Ellis Horwood Series in Geology. Chichester: Ellis Horwood; ISBN 0 853127611 (Ellis Horwood); 0470203897 (Halsted Press). 125(3) xi + 441 pp.

[3] Edimeh PO, Eneji IS, Oketunde OF \& Sha'ato R (2011) Physico-chemical parameters and some Heavy metals content of Rivers Inachalo and Niger in Idah, Kogi State. Journal Chemical Society Nigeria 36 (1): 95-101.

[4] Ezeribe AI, Oshieke KC \& Jauro A (2012) Physico-chemical properties of Well water Samples from some villages in Nigeria with cases of Stained and mottle teeth. Science World Journal, 7(1). 1-3. ISSN: 1597-6343.

[5] Lubyanka R \& Vladana R (2018) Arsenic in water: determination and removal. Arsenic- Analytical and toxicological studies pp 663.

[6] Monique B \& Fritz HF (2003) Occurrence, Toxicity, Speciation, Mobility, Wiley online library, (31) pp 9-18 https://doi.org/10.1002/aheh.200390025

[7] National Center for Biotechnology Information (2020) PubChem Database. Arsenic, CID=5359596, https://pubchem.ncbi.nlm.nih.gov/compound/Arsenic.

[8] Sasikaran S, Sritharan K, Balakumar S \& Arasaratnam V (2012) Physical, chemical and microbial analysis of bottled drinking water. Ceylon Medical Journal, 57. https://doi.org/10.4038/cmj.v57i3.4149.

[9] Shiv S, Uma S \& Shikha L (2014) Arsenic contamination of groundwater: A review of source, prevalence, Health Risks and strategies for mitigation. The scientific world journals. https://doi.org/10.1155/2014/304524.

[10] United States Environmental Protection Agency (2003) Environmental Protection Agency EPA's Report on the Environment (2003 Draft). Available at https://cfpub.epa.gov.recordisplay.

[11] Walter H W (2015) Molecular Mechanisms of Arsenic Toxicity. In Advances in Molecular Toxicology (9), pp. 35-77. Elsevier. https://doi.org/10.1016/B978-0-12-802229-0.00003-7.

[12] World Health Organization. (2018) Arsenic. https://www.who.int/news-room/fact-sheets/detail/arsenic.

[13] Wuana RA \& Okieimen F E (2011) Heavy Metals in Contaminated Soils: A review of Sources, Chemistry, Risks and Best Available Strategies for Remediation. International Scholarly Research Notices.2011, 1-20. Available at https://doi.org/10.5402/2011/402647. 